\title{
Modelling GDP and FDI for Czech Republic_-Impulse Response Functions in VECM
}

\author{
Aneta Kosztowniak \\ Kazimierz Pułaski University of Technology and Humanities in Radom, Radom, Poland \\ National Bank of Poland, Warsaw, Poland
}

\begin{abstract}
This article presents detailed the impact of factors of production on economic growth in the Czech Republic in the period 1994-2015. The main research focuses on the impact of foreign direct investment (FDI) and on answering the question whether between GDP and FDI there is a causality relationship. The VECM model using the impulse responses function confirmed the occurrence of a bi-directional relationship between FDI and GDP in the Czech Republic. According to the empirical evidence, it was confirmed that the consumption demand and trade had a strong impact on GDP. However, these findings demonstrated that a weak FDI had an impact on economic growth. ${ }^{1}$
\end{abstract}

Keywords: FDI, GDP, Czech Republic, VECM, the impulse response function

\section{Introduction}

In Czech Republic, the foreign direct investment (FDI) inflow has been increasing over the past 25 years and it has been seen as one of the key factors the economic growth. Therefore, the purpose of this article is to analyse the impact of factors of production (altogether from FDI) on economic growth in the Czech Republic in the period 1994-2015. In this context, it focuses on the impact of FDI and tries to answer the question whether there is a relationship between GDP and FDI. The main goal focuses on the research whose factors of production have a strong influence on economic growth and FDI inflows. The answer to this question is very important for economic policy to sustain the growth rate. However, both the FDI theory and empirical studies for individual countries indicate that the inflow of such investment entails different economic effects. The study uses the VECM model (Vector Error Correction Method) with using the impulse responses function. The research bases on statistics from the OECD, UNCTAD, and IMF Internet databases, for the period 1994-2015.

\section{Theoretical Approach}

FDI effects on host country economic growth are often debated in the literature because of their controversial character. The effect between FDI and GDP can be either favourable or unfavourable. Several

\footnotetext{
Acknowledgements: The views expressed in this paper are the views of the author and do not necessarily reflect those of the National Bank of Poland.

Aneta Kosztowniak, Ph.D., assistant professor of Economics, Department of Economic Policy and Banking, Kazimierz Pułaski University of Technology and Humanities in Radom, Radom; National Bank of Poland, Statistical Department, Warsaw, Poland.

Correspondence concerning this article should be addressed to Aneta Kosztowniak, Department of Economic Policy and Banking, University of Technology and Humanities in Radom, 31 Chrobrego Street, Radom 26-600, Poland.

1 This paper presents author's the additional empirical findings towards the paper under the title: Decomposition of Relationship Between Factors of Production, FDI and GDP for Czech Republic - in VECM, which could not be presented on account of volume restrictions of the article.
} 
studies find a clear positive link, while others do not. The views concerning the connection between FDI and economic growth reveal foreign capitals importance on host country economy and the differences among approaches appear because of variables selection (Borensztein, De Gregorio, \& Lee, 1995; Chowdhury \& Mavrotas, 2005). However, majority of existing theoretical models imply that FDI is beneficial for host country's economic growth, e.g., the traditional economic theory (law of diminishing returns). The important theoretical concept defining the relationship between international capital flows in the form of FDI and economic growth is Dunning's theory of the international investment position evolution (Dunning \& Narula, 1996). It explains decisions concerning FDI location by different degrees of economic development of individual countries. Dunning (1998) noticed interrelationships between an international investment position (net values of investment per capita) and the economic development level measured by domestic product per capita. Theoretical literature also suggests that the positive relationship between FDI and growth is not necessarily true. Herzer, Klasen, and Howak-Lehmann (2008) argued that if FDI considerably "crowds out" domestic investments, then it is possible to have a growth decelerating impact on the recipient country. Moreover, causality relation between FDI and growth is not necessarily unidirectional, because the causality can work in both directions.

\section{Empirical Studies Relevant to Czech Republic and CEE Countries}

Many empirical contributions have tried to explain the relationship between FDI and growth. Vehorn and Vasarevic (2011) proved that FDI and domestic investment were statistically significant determinants of economic growth in CEE countries in the period 1992-2007. The research of Damijan, Kostevec, and Rojec (2013) for six CEE countries (Czech Republic, Estonia, Hungary, Poland, Slovenia, and Slovakia) shows that in the first decade of transition, in the period 1993-2001, in general, productivity growth was positively correlated with FDI. In research, Kosztowniak (2016) dealt with the impact of the factors of production on economic growth in Poland in the years 1992-2012 with particular focus on the impact of FDI, and using the VECM she strives to verify whether a causality relationship occurs between GDP and FDI. The impulse responses and variance decomposition analysis confirm the bi-directional relationships between FDI and GDP in Poland. However, the impact of GDP on attracting FDI inflows to Poland is stronger than that of FDI on GDP growth. A weaker FDI impact on economic growth results from the structure of inflowing FDI in which, unfortunately, debt securities prevail.

Next important research concerns on sourcing patterns of FDI activity and their impact on domestic economy for Western and CEE countries (for Czech Republic also) covers the time period 2001-2007. According to Nikolovová (2013), FDI has the potential to positively influence the economy of the host country through backward inter-industry linkages, but this potential is not fully exploited yet in CEE countries, possibly due to a persisting technology gap. Similar views are presented for example Gorynia, Nowak, and Wolniak (2008). Moreover, the research examining the impact of the factors of production on economic growth in the Czech Republic in the years 1994-2015 by using the OLS (Ordinary Least Square) method (Kosztowniak, 2017) indicates that changes in GDP growth strongly explain changes of final consumption expenditure of households, following exports of goods and services (positive), and imports of goods and services (negative), sequentially by changes in gross fixed capital formation and finally final consumption expenditure of general government. The FDI variable was not a significant factor determining GDP growth in the Czech Republic. 


\section{Research Procedure and the Choice of Econometric Model}

In order to analyse the relationship between changes in GDP values and factors of production in the Czech Republic in the years 1994-2015, the final formula for the production function was developed which looks as follows:

$$
Y_{t}=f\left(E C E H_{t}, E C E G G_{t}, G F C F_{t}, F D I_{t}, E x G S_{t}, \operatorname{ImGS}_{t}, R \& D_{t}, E m p l o y_{t}\right)
$$

The model used consists of the dependent variable (GDP) and eight independent variables (in million USD, constant prices, 2010), where: GDP (Gross Domestic Product), FCEH (Final Consumption Expenditure of Households), FCEGG (Final Consumption Expenditure of General Government), GFCF (Gross Fixed Capital Formation), FDI (Foreign Direct Investment) Inflow, ExGS (Exports of Goods and Services), ImGS (Imports of Goods and Services), R\&D (Expenditure on Research and Development), Employ (total employment in the economy (number of persons in thousands)), $\mathrm{t}$ - period. The above mentioned explanatory variables for production function (GDP) and research methodology were adopted by many authors, among others by Chowdhury and Mavrotas (2005); Driffield and Jindra (2012), who analyzed the FDI effect on economic growth in host countries.

In order to verify the selection of variables for the model, the correlation matrix was determined. The critical value of the Pearson linear correlation coefficient was 0.4227 for $n=22$. In general, correlation coefficients differ significantly from the critical value. Adoption of first differences of logarithms allowed model estimation while maintaining stationarity of data. To verify stationarity of the analyzed time series, the Augmented Dickey-Fuller (ADF) test was used, in the following form:

$$
\Delta y_{t}=\mu+\delta_{t-1}+\sum_{i=1}^{k} \delta_{i} \Delta y_{t-1}+\epsilon_{t}
$$

The value of the test statistic was calculated with the use of the formula:

$$
A D F=\frac{\hat{\delta}}{s_{\hat{\delta}}}
$$

where $\hat{\delta}$ means the parameter evaluation, and $s_{\hat{\delta}}$ is the parameter estimate error.

For all analyzed variables, it was found out that they lacked stationarity of time series, but a unit root $a=1$ occurred at process I(1). For each series, the ADF test was conducted separately with an absolute term and with an absolute term and linear trend. For most statistics, the values $\tau_{o b l .}$ are higher than critical values $\tau_{\text {kryt. }}$, which proves non-cointegrated series (Johansen, 1988). Empirical significance levels of $p$-values are mostly lower than 0.05 , which indicates stationary series.

The results obtained by Engle and Granger confirm complete co-integration. It is evidenced by the value of the test statistic $\tau_{o b l}$, the level of the asymptotic $p$-values and process integration. For each process used, there is a unit root $\mathrm{a}=1$ and process I(1). Considering the assumption that if $\tau$ in respect of the absolute value is higher than the critical value, it means that the series are stationary. Hence, we can conclude that both series $y_{t}$ and $x_{t}$, despite the fact that they are non-stationary, are co-integrated and they do not threaten obtaining apparent regression. Results of the Johansen test (with trace and with eigenvalue) show that at the significance level of 0.05, co-integration of order one occurs. Verification of co-integration conducted with the use of the Engle-Granger test and Johansen test confirmed the occurrence of co-integration and in this way justified the use of the VECM model. 


\section{VECM Model}

In accordance with the Granger representation theorem, if the variables $y_{t}$ and $x_{t}$ are order one integrated I(1) and are co-integrated, then the interdependence between them can be presented as the error correction model (Lupiński, 2013). The general form of the VECM model can be written down as follows:

$$
\Delta Y_{t}=\Gamma_{1} \Delta Y_{t-1}+\Gamma_{2} \Delta Y_{t-2}+\ldots+\Gamma_{k-1} \Delta Y_{t-k+1}+\pi Y_{t-k}+\varepsilon_{t}=\sum_{i=1}^{k-1} \Gamma_{i} \Delta Y_{t-i}+\pi Y_{t-k}+\varepsilon_{t},
$$

where:

$$
\Gamma_{i}=\sum_{j=1}^{i} A_{j}-I, i=1,2, \ldots, k-1, \Gamma_{k}=\pi=-\pi(1)=-\left(I-\sum_{i=1}^{k} A_{i}\right),
$$

$I$ is the unit matrix.

The lag order for the VAR/VECM model was determined on the basis of the following information criteria estimation: the Aikake information criterion (AIC), Schwartz-Bayesian information criterion (BIC), and Hannan-Quinn information criterion (HQC). The results of these criteria showed the lag order 1 . While analyzing stability of the VAR/VECM model, the unit root test was carried out, which indicated that in the analyzed model the equation roots in respect of the module are lower than one. This means that the model is stable. The Ljung-Box test was used to verify the occurrence of autocorrelation between the variables of the VECM model. In this test, the verifying test statistic uses the autocorrelation function (ACF) in the form:

$$
Q^{\prime}=T(T+2) \sum_{j=1}^{m} \frac{r_{j}^{2}}{T-j}
$$

where: $T$-length of time series (number of observations), $j$-rank of autocorrelation, $j=1,2,3 \ldots, p$, $\mathrm{r}_{\mathrm{j}}^{2}$-autocorrelation coefficients (ACF), $m$-the test level. The critical value of the test is based on $\chi^{2}$ distribution with $m$ degrees of freedom. The results of the Ljung-Box test for the estimated models (1-9), i.e., for all examined variables, showed that the empirical p-levels were higher than the nominal significance level $\alpha=0.05$. This authorized us to state the lack of autocorrelation in the residual process.

\section{Empirical Results-Impulse Response Functions}

The graphs of GDP response functions to impulses of the model variables indicate that with time the impulses of the nine variables exert both the increasing as well as weakening impact on future values. Responses of the GDP dynamics revealed the increasing/enhancing effect of the impulses of three variables: FCEH, ExGS, ImGS in the period of 1 year, followed by the decreasing effect in periods 2-3, and stabilizing effect from period 4 onwards. These results can be interpreted in such a way that the pillars of GDP growth in the Czech Republic are: consumption demand of households and trade (exports and imports of goods and services). The results of research in this respect are important from the point of view of their application. They mean that the economic policy should use the tools which support the household's demand and trade. Considering the fact that the GDP response to the above mentioned impulses of three variables is the strongest in the first two to three years, it means that they should be the focus of interest of the short-term policy generating quick favourable effects.

On the other hand, the fading/weakening character of the GDP response was revealed to impulses derived from six variables: FCEGG, GFCF, FDI inflows, R\&D, and Employment in the first year and then it increased 
(rebound) in periods 2-3 and stabilized from period 4 onwards. The fading GDP responses to the impulses from the above mentioned variables are also important from the point of view of their application. The fact is that these variables should stimulate economic growth, but in the case of the Czech Republic they actually do not. This means that the amount of expenditure, its structure, and changes in it over the period examined were unfavourable. For this reason, it seems that they require detailed analysis and changes so that in the future they could support economic growth.

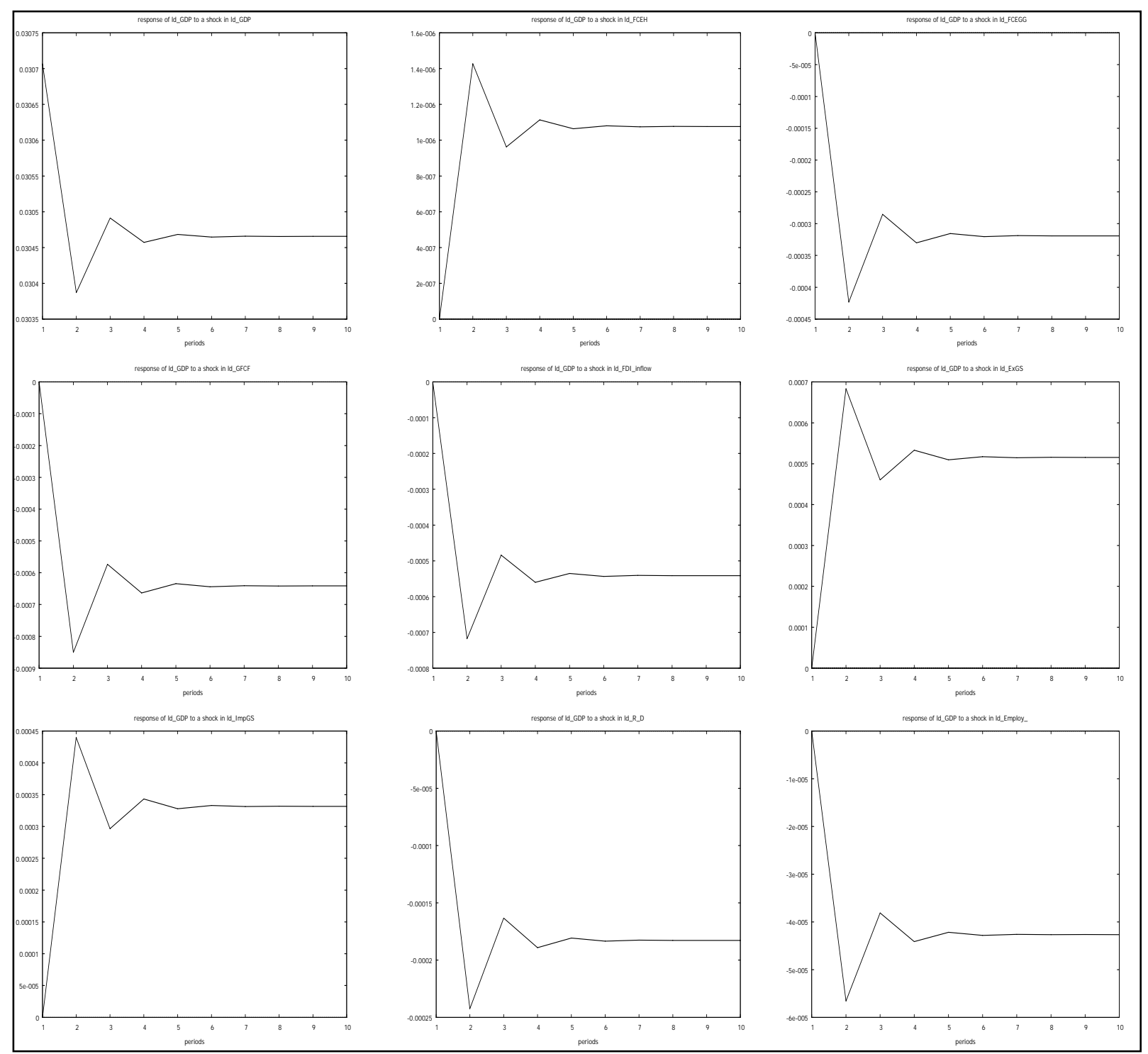

Figure 1. Graphs of GDP impulse responses in the Czech Republic, the VECM model. Source: author's own compilation (OECD, 2017; UNCTAD, 2017).

The graphs of the FDI inflow function responses indicate that they increased in result of the impulses coming from three variables, e.g., FCEH, ExGS, and ImGS in the period of the first two years, weakened in periods 3-4, and stabilized in the following periods. The growing response of FDI inflows to the above named variables: FCEH, ExGS, and ImGS can be interpreted as their being favourable determinants of FDI inflows to the Czech Republic. These determinants are important for foreign investors and their changes decide about 
attractiveness of the host economy for investment.

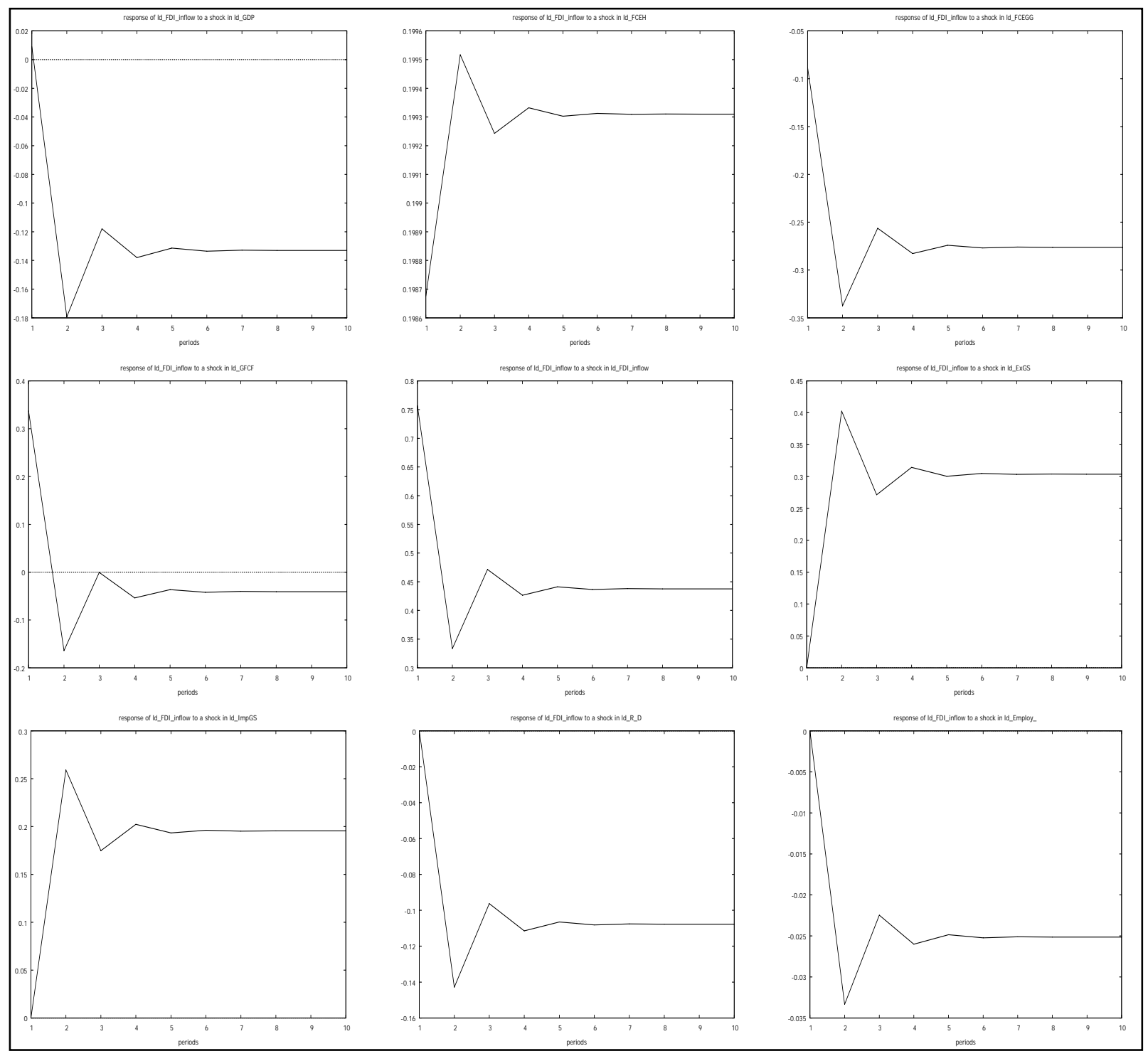

Figure 2. Graphs of FDI impulse responses. Source: author's own compilation (OECD, 2017; UNCTAD, 2017).

On the other hand, FDI inflows showed the fading character in response to the impulses coming from six variables: GDP, FCEGG, GFCF, own FDI inflow impulses, and Employment. The fading/weakening trend was evident in periods 1-2, and it weakened in period 3 and stabilized from period 4 of the forecast. Thus, these variables can be treated (at least in the short-run) as the determinants hindering FDI inflows to the Czech Republic.

\section{Discussion and an Attempt at Their Explanation}

The fact that FDI inflows are weakening in response to GDP can be interpreted as follows: Foreign direct investors do not condition investment inflows on the growth rate of Czech economy, but they attach more importance to treating this economy as a location for their own production. The Czech market is one of the links of their production chain. These entities import raw materials, products (components) from their own 
parent companies and foreign branches to the Czech market where they process them (taking advantage of the relatively cheap labour force) and they re-export them to foreign markets, but now in the form of finished goods. Moreover, the reasons for a weak impact of FDI inflows on economic growth in the Czech Republic in the years 1994-2015, diagnosed on the basis of impulse responses, can be threefold, e.g., rapid fluctuations in FDI inflows (unstable), low share of foreign capital (FDI) in capital accumulation in the Czech economy, and maintaining unfavourable structure of FDI inflows (by high level of debt instruments). As a result of a strong amplitude of fluctuations in FDI inflows caused, for example, by partial withdrawal of capital, merger, and overtake processes or payment of dividends, potentially favourable effects of FDI inflows on economic growth in the Czech Republic were limited (Pawłowska, 2012). Considerable fluctuations of FDI inflows prove that foreign investors have not pursued a stable, long-term investment policy in the Czech market. The level of re-investment of profits from FDI and implementation of new projects was kept low. The attitude of foreign investors also indicates the so-called low level of investment risk aversion towards the Czech market.

\section{Conclusions}

The GDP as well as FDI response functions to the impulses indicate that they responded most strongly in the first year (1-2) to the stimuli coming from the examined variables and got stabilized after 3-4 years of the forecast. GDP showed an increasing tendency to the impulses coming from households' consumption expenditure and exports and imports of goods and services. On the other hand, GDP showed a weakening tendency towards such impulses as: GFCF, FDI inflows, expenditure on R\&D, and changes in employment. The FDI inflow responses were stronger in the case of impulses coming from household consumption expenditure and exports and imports of goods and services. Thus, these variables can be treated as the determinants stimulating FDI inflows to the Czech economy. On the other hand, FDI inflows showed the fading effect in response to the impulses coming from GDP, final government consumption expenditure, gross outlays on fixed assets, FDI inflow own impulses, and employment.

\section{References}

Borensztein, E., De Gregorio, J., \& Lee, J. W. (1995). How does foreign direct investment affect economic growth? NBER Working Paper, No. 5057.

Chowdhury, A., \& Mavrotas, G. (2005). FDI and growth: A causal relationship. United Nations University, WIDER, Research Paper, No. 25.

Damijan, J. P., Kostevec, C., \& Rojec, M. (2013). Global supply chains at work in central and eastern European countries: Impact of FDI on export restructuring and productivity growth. LICOS Discussion Paper Series, 332, 1-36.

Driffield, N., \& Jindra, B. (2012). Challenging the production function approach to assess the developmental effects of FDI. European Journal of Development Research and Training Institutes, 24, 32-37.

Dunning, J. H., \& Narula, R. (1996). The investment development path revisited: Some emerging issues. In J. H. Dunning and R. Narula (Eds.), Foreign direct investment and government catalysts for economic restructuring. London: Routledge.

Dunning, J. H. (1998). Transactional corporations: An overview of relations with national governments. New Political Economy, $3(2)$.

Gorynia, M., Nowak, J., Wolniak, R. (2008). Poland's investment development path and industry structure of FDI inflows and outflows. Journal of East-West Business, 14(2), 189-212.

Herzer, D., Klasen, S., \& Howak-Lehmann, F. (2008). In search of FDI-led growth in developing countries: The way forward. Economic Modeling, 25(5).

Johansen, S. (1988). Statistical analysis of cointegration vectors. Journal of Economic Dynamics and Control, 12(3), $231-254$.

Kosztowniak, A. (2016), Verification of the relationship between FDI and GDP in Poland. Acta Oeconomica, 66(2), $307-332$. doi:10.1556/032.2016.66.2.6 
Kosztowniak, A. (2017). Economic growth model for the Czech Republic and FDI inflow significance-OLS method examples (pp. 259-267). In J. Vopova, V. Douda, R. Kratochovil, and M. Konecki (Eds.). Multidisciplinary Academic Conference On Management, Marketing And Economics, MAC Prague Consulting s. r. o., Czech Republic.

Łupiński, M. (2013). Comparision of alternative approach to VaR evaluation. Ekonomika i Orgnizacja Przedsiębiorstwa (ang. Economics and the Organization of the Enterprise), 64(7), 3-16.

Nikolovová, P. (2013). Sourcing patterns of FDI activity and their impact on the domestic economy. Finance a úverr-Czech Journal of Economics and Finance, 63(3), 300-301.

OECD. Stat. (2017). Data by theme. Retrieved from http://stats.oecd.org

Pawłowska, M. (2012). Competition, concentration a d foreign capital in the Polish banking sector (prior and during the financial crisis). National Bank of Poland Working Paper, 130, Warsaw.

UNCTAD. Stat. (2017). Retrieved from http://unctadstat.unctad.org

Vehorn, C. L., \& Vasarevic, A. (2011). FDI and macroeconomic policies, central and Eastern European countries, Zagreb. International Review of Economics \& Business, 14(1), 23-34. 